\title{
Application of the Right to Permanent Sovereignty over Natural Resources for Indigenous Peoples: Assessment of Current Legal Developments
}

\author{
Endalew Lijalem Enyew* \\ PhD Candidate, K.G. Febsen Centre for the Law of the Sea (FCLOS), \\ Faculty of Law, UiT -The Arctic University of Norway, Tromsø, Norway
}

\begin{abstract}
The right to Permanent Sovereignty over Natural Resources (PSNR) emerged in the era of decolonization. As a reaction to the irresponsible exploitation of natural resources by colonial powers, peoples under colonial rule and newly independent developing states asserted the right to control and dispose of their own natural resources. The UN General Assembly recognized and reinforced these claims by adopting a series of resolutions relating to the right to PSNR so as to facilitate the process of decolonization. However, the subjects of the right to PSNR have expanded to include 'all peoples' due to legal developments in international law pertaining to the right to self-determination of peoples and other human rights standards. This article explores the contemporary application of the right to PSNR for indigenous peoples, by virtue of their being 'peoples', tracing various developments in international law relating to indigenous peoples since the inception of PSNR in the 1950s.
\end{abstract}

Keywords: United Nations General Assembly; Decolonization; Self-determination; Cross-border resource management; Human rights treaty bodies; Inuit; Sami

Responsible Editor: Øyvind Ravna, UiT The Arctic University of Norway, Tromsø, Norway.

Received: July 2017; Accepted: October 2017; Published: November 2017

\section{Introduction}

The right to Permanent Sovereignty over Natural Resources (PSNR) is defined as the right to dispose freely of natural resources. ${ }^{1}$ The right to PSNR emerged during the period of decolonization with the objective of protecting the resources of peoples living under colonial domination, and for "providing newly independent States with control over resources previously held by colonial interests". ${ }^{2}$ With the development

${ }^{\star}$ Correspondence to: Endalew L. Enyew, Faculty of Law, UiT -The Arctic University of Norway, Po. Box 9037, Tromsø, Norway. Email: Endalew.l.enyew@uit.no 
of various human rights standards, however, the right to PSNR has evolved and become not only a right of States, but also a human right of 'all peoples'.

In line with this evolution, the question arises as to whether indigenous peoples are the subjects of the right to PSNR by virtue of their being 'peoples' within the meaning of international law. It is this question that this article explores, i.e. the contemporary application of the right to PSNR for indigenous peoples, through an assessment of current legal developments, practices of human rights treaty monitoring bodies, and certain state treaty practices.

The article begins in section two with a discussion of the concept, genesis, and legal basis of PSNR, as well as the evolution of to PSNR from a right of States to a human right applying to 'all peoples'. Section three examines: scholarly debate on the application of the right to PSNR for indigenous peoples; recognition of PSNR in recent human rights instruments and practices of treaty bodies; and types of natural resources over which indigenous peoples have permanent sovereign right. Section four discusses certain examples of the exercise of the right to PSNR by indigenous peoples, particularly the Inuit and the Sámi, in the context of cross-border resource use and management, to determine whether, how and the extent to which States have met their obligation to allow indigenous peoples to freely manage and dispose of their natural resources. Finally, section five provides concluding remarks.

\section{The Meaning, Legal Basis and Evolution of the Right to PSNR}

\subsection{The Meaning and Origin of the Right to PSNR}

In general terms, the right to PSNR can be defined as the right of all States and/ or peoples to dispose freely of the natural resources, of any kind, found within their territory, including the maritime space. ${ }^{3}$ The term "dispose of" in relation to PSNR means "to have at one's disposal powers of decision making as to how natural resources are to be used". "Thus, the rights that emanate from the right to PSNR, inter alia, include the right to decide the manner of resource exploitation; to control the use, conservation and management of natural resources; to grant license for the exploitation of resources; and to supervise the activities of foreign companies and take measures to ensure that such activities comply with its laws, rules and regulations. ${ }^{5}$

The historical roots of the right to PSNR dated back to the period of decolonization in the early 1950s where both peoples living under colonial rule as well as newly independent developing States began to assert the right to sovereignty over natural resources found within their territory. ${ }^{6}$ In the $19^{\text {th }}$ century the expansion of colonial occupation was primarily motivated by the desire of the colonizing European States to exploit the resources of non-European territories. ${ }^{7}$ Accordingly, colonial countries engaged in a massive exploitation of the valuable natural resources of their colonies by granting concessions to foreign extractive companies on favourable terms. ${ }^{8}$

The right to PSNR emerged as a reaction to the irresponsible exploitation of the natural resources of peoples under colonization by the colonial powers and their companies. 


\section{E. L. Enyew}

While the peoples still living under colonial rule invoked the principle of PSNR to obtain a fair share of the benefits arising from the exploitation of natural resources, ${ }^{9}$ newly independent developing States used the principle to regain control over their natural resources taken by colonial powers and to protect themselves from continuing economic colonization. ${ }^{10}$ Newly independent States considered colonial period concessions as a threat to their PSNR, because those concessions granted excessive areas of land for long period to a single company without giving the host States sufficient authority to control the activities of the former. ${ }^{11}$ These newly independent States rejected the colonial States' argument that the right to PSNR had to comply with the doctrines of state succession and pacta sunt servanda, which require the new States to honour concessionary rights that western companies had acquired prior to independence regardless of their content. ${ }^{12}$ Accordingly, newly independent States maintained that PSNR allowed them to end or revise colonial time concessions which could "survive the change of sovereignty only at the express consent and wish of the new [State]". ${ }^{13}$

In sum, the principle of PSNR originally arose to reinforce the colonial peoples and newly independent States' claim to control over their natural resources without interference by (former) colonial States and their companies. Hence, the initial subjects of the right of PSNR were non-self governing peoples and newly independent developing States. Yet, after the era of decolonization, the right to PSNR has become a right of all States irrespective of their status. The next section deals with the legal basis of States' right to PSNR.

\subsection{The Legal Basis for the Right of States to PSNR}

The United Nations served as a forum for the emergence and development of the right to PSNR. The UN General Assembly began adopting a series of resolutions relating to the right to PSNR in the 1950s. However, it was resolution 1803 (XVII) of 1962 that laid the foundation for, and gave prominence to, the right under international law with the objective of facilitating the decolonization process. Resolution 1803 recognizes "the inalienable right of all States freely to dispose of their natural wealth and resources in accordance with their national interests, and on respect for the economic independence of States". ${ }^{14}$ The right of PSNR was further strengthened upon the passing of the Charter of Economic Rights and Duties of States in 1974, which addressed the economic relationship of developing and industrialized States. The Charter states that "every State has and shall freely exercise full permanent sovereignty including possession, use and disposal, over all its wealth, natural resources and economic activities". ${ }^{15}$ As such, the Charter outlined some of the essential rights that emanate from the right to PSNR.

The right of States to PSNR covers all natural resources found both on land and within their maritime boundaries. The UNGA Res. 3016(XXVII) ${ }^{16}$ of 1972 and UNA Res. 3171 (XXVIII) ${ }^{17}$ of 1973 specifically provides for States' right to permanent sovereignty over marine resources. Operative paragraph 1 of the two resolutions recognizes in identical terms "the right of States to permanent sovereignty over all their natural resources on 
land within their international boundaries as well as those found in the seabed and the subsoil thereof within their national jurisdiction and in the superjacent waters".

Subsequent international treaties have also recognized the sovereign right of all coastal States over marine resources. For example, in its various provisions the United Nations Convention on the Law of the Sea (LOSC) ${ }^{18}$ expressly recognizes the sovereign rights of all coastal States to exploit their marine resources. Article 193 of the LOSC provides a general provision stating that: "States have the sovereign right to exploit their natural resources pursuant to their environmental policies and in accordance with their duty to protect and preserve the marine environment". More specifically, articles 56 (1) (a) and 77 of the LOSC recognize the sovereign rights of coastal States to explore and exploit, conserve and manage the natural resources of the Exclusive Economic Zone (EEZ) and the Continental Shelf respectively. Similarly, the Convention on Biological Diversity (CBD), which regulates both terrestrial and marine resources, explicitly recognizes the sovereign right of all States "to exploit their own resources pursuant to their own environmental policies". ${ }^{19}$

In conclusion, the right to PSNR, which originally emerged as a political claim by colonized peoples and newly independent States attempting to control their natural resources, has later become a recognized principle of international law applicable to all States. ${ }^{20}$ It aims to empower every State with the inalienable right to freely dispose of its natural resources in accordance with its national interests, and economic and environmental policies. Thus, all States, regardless of whether they are newly emerging, developing or developed, have become holders of the right to PSNR as an integral part of their sovereignty and political independence recognized under article 2 of the UN Charter. Elian notes that "the State's definitive, indisputable, and uncontested supremacy over its territory involves a reality which is beyond discussion: permanent sovereignty over the resources of that territory"; ${ }^{21}$ and the territory of a State comprises both land and maritime boundaries. ${ }^{22}$

\subsection{From a Right of States to a Human Right of Peoples}

The right of States to PSNR is indisputable as an integral part of their sovereignty and territorial integrity. However, the right has also evolved into a human right of 'all peoples'. It was resolution 1803 which initially linked the right to PSNR and peoples declaring that:

The right of peoples and nations to permanent sovereignty over their natural wealth and resources must be exercised in the interest of their national development and of the well-being of the people of the State concerned. ${ }^{23}$

The resolution made it clear that 'peoples' are subjects of the right to PSNR; that they have the right to be involved in decisions regarding the use of their natural resources; and that it requires the natural resources to be used for the sole benefit of the peoples concerned. The use of language, which specifically targeted peoples rather than States marked a significant step forward in the recognition of the right to PSNR as a peoples' right. ${ }^{24}$ 


\section{E. L. Enyew}

The right to PSNR has become a concrete human right of peoples upon its incorporation into various human rights treaties. It is explicitly provided for under common article 1(2) of the International Convention on Civil and Political Rights and the International Convention on Economic, Social and Cultural Rights (twin human rights conventions), which reads:

All peoples may, for their own ends, freely dispose of their natural wealth and resources without prejudice to any obligations arising out of international economic co-operation, based upon the principle of mutual benefit, and international law. In no case may a people be deprived of its own means of subsistence. ${ }^{25}$

Similarly, article 25 of ICESCR and article 47 of ICCPR in identical wording reaffirm the right to PSNR stating that: "Nothing in the present Covenant[s] shall be interpreted as impairing the inherent right of all peoples to enjoy and utilize fully and freely their natural wealth and resources". ${ }^{26}$ Thus, the twin human right conventions recognize the right to PSNR as an inherent right of peoples thereby authorizing them to freely dispose of their natural resources "for their own ends", including to fulfil their means of subsistence.

At the regional level, the African Charter on Human and Peoples' Rights provides for the rights of peoples to PSNR. The Charter recognizes all peoples as having "the unquestionable and inalienable right to self-determination". ${ }^{27}$ It further states that "all peoples shall freely dispose of their wealth and natural resources. This right shall be exercised in the exclusive interest of the people. In no case shall a people be deprived of $i t " .{ }^{28}$ The African Charter, thus, provides for a reinforced expression of the right to PSNR in detailed and stronger terms than the twin human rights conventions. It makes the right to PSNR unquestionable, inalienable, and absolute, declaring that "in no case shall a peoples be deprived of it [their right to freely dispose of their natural resources]". ${ }^{29}$ The peoples are the sole beneficiaries of the exploitation of natural resources, and are entitled to its lawful recovery and adequate compensation in the event of dispossession. ${ }^{30}$

In summary, the above mentioned human rights instruments confirm that all peoples are the holders of the right to PSNR, while States parties are duty bound to respect and promote the realization of the right to comply with their human rights commitments. Yet, none of the instruments defines the term 'peoples'. This raises the question as to whether indigenous peoples are 'peoples' entitled to the right of PSNR, an issue explored in the next section.

\section{Indigenous Peoples: Holders of the Right to PSNR?}

The question as to whether indigenous peoples are holders of the right to PSNR is related to the issue of whether they are 'peoples' under international law, capable of exercising the right to self-determination in general and the right to economic selfdetermination in particular. Each of these topics is discussed below. 


\subsection{Indigenous Peoples' Right to Self-determination}

In classical international law, indigenous peoples were denied the right to self-determination on the ground that the right only applied to "civilized" sovereign nations; and not to "uncivilized" indigenous peoples who did not constitute a nation. Indigenous peoples were considered "uncivilized" as they neither had sedentary lifestyles nor were they Christians, measures of civilization at the time. ${ }^{31}$ Debate over the application of the right to self-determination to indigenous peoples continued even after the incorporation of the right in the major international human rights instruments based on differing interpretations of the term "peoples". States generally maintained that the right to self-determination applies only to peoples under colonial domination; ${ }^{32}$ or to "aggregate populations" of independent States, ${ }^{33}$ and not to any portion of the population of a State. The implication was that indigenous peoples were not considered "peoples" entitled to self-determination.

Nonetheless, limiting the application of the right to self-determination to peoples under colonial domination and to the entire population of a State is restrictive, and has received little support in the post-colonial period and in the era of multicultural society. ${ }^{34}$ Such restrictive understanding contradicts with the notion that self-determination is a continuing right - a right that evolves over time to accommodate the contemporary needs of the international community and particularly indigenous peoples. ${ }^{35}$ Accordingly, international law and practices of human rights bodies have accepted the application of the right to self-determination in the context of indigenous peoples in recent decades. Even though the ILO Convention Concerning Indigenous and Tribal Peoples in Independent Countries (ILO Convention No. 169) does not contain a separate express provision dealing with the right to self-determination, ${ }^{36}$ the recently adopted indigenous-specific human rights instruments have unambiguously recognized the right of indigenous peoples to self-determination. Common article 3 of UNDRIP and the American Declaration on the Rights of Indigenous Peoples (ADRIP) replicate common article 1 of the twin human rights conventions in the context of indigenous peoples' right to self-determination. Yet, the two instruments limit the scope of application of indigenous peoples' right to self-determination to the exercise of autonomy or self-government in matters relating to internal and local affairs. ${ }^{37}$ Hence, these indigenous-specific human rights instruments clearly recognize the internal self-determination of indigenous peoples. ${ }^{38}$

The practices of human rights treaty monitoring bodies have also embraced the right of indigenous peoples to self-determination under their respective conventions. In particular, the Human Rights Committee (HRC) and the Committee on Economic, Social and Cultural Rights (CESCR) have frequently affirmed the right of indigenous peoples to internal self-determination, invoking common article 1 in their concluding observations on reports of a number of countries. ${ }^{39}$ In short, indigenous peoples have been widely recognized as "peoples" capable of exercising the right to internal selfdetermination in recent decades. The next section explores whether, and to what extent, indigenous peoples' right to internal self-determination includes the right to PSNR. 


\section{E. L. Enyew}

\subsection{Does Indigenous Internal Self-determination include the Right to PSNR?}

Even though the right of indigenous peoples to internal self-determination has been widely recognized in recent years, it remains debatable whether the right encompasses their right to dispose freely of their natural resources as incorporated in common article 1 (2) of the twin human rights conventions and article 21 of the African Charter on Human and Peoples' Rights. The following subsections explore this issue in more detail. However, before discussing the application of the right to PSNR for indigenous peoples, it is useful to first (re)define the term sovereignty or sovereign right over natural resources as applied to indigenous peoples.

\subsubsection{Qualifying the Meaning of the Right to PSNR}

The meaning of the term PSNR when used in reference to indigenous peoples is not the same as when it is applied to States. Miranda argues that "sovereignty attributed to indigenous peoples may be something different, or less, than what has been traditionally associated with the sovereign rights of States". ${ }^{40}$ The 'sovereignty' of indigenous peoples over natural resources, thus, should be understood consistently with the right to internal self-determination. Daes notes that the meaning of the term 'sovereignty' in relation to indigenous peoples' assertion of rights to natural resources should be modestly understood to mean a "legal right to control, use and manage natural resources" ${ }^{41}$ It is a right to exercise ownership, use, and management authority over natural resources located within their traditional territories. ${ }^{42}$ Indigenous peoples' sovereign right over natural resources, thus, covers "all the normal incidents of ownership right: the right to use or conserve resources, the right to manage and control access to resources, the right to freely dispose of or sell resources and related interests". ${ }^{43}$

There exists a clear link and overlap between the right to PSNR and the right to property. Indeed, the right to PSNR, being the economic dimension of the right to self-determination, is an umbrella right from which other substantive and procedural rights relating to natural resources emanate. The right to property is one of the most relevant rights guided by the right to PSNR. Underlining this intimate link, Richard Barnes has introduced the general concept of "territorial sovereignty as property". ${ }^{44}$ In the specific context of indigenous peoples, Pereira and Gough note that the right to PSNR frames, and establishes important parameters for, the allocation of indigenous peoples' property rights in natural resources ${ }^{45}$ Daes underlines the overlapping nature of the two rights describing indigenous peoples' right to PSNR as "a collective right by virtue of which the State is obliged to respect, protect, and promote the governmental and property interests of indigenous peoples (as collectives) in their natural resources" ${ }^{46}$ In other words, the right to PSNR of indigenous peoples is actually expressed or implemented in the form of the exercise of collective property rights over natural resources by the relevant indigenous communities. Similarly, Fox-Decent and Dahlman articulate the concept of "indigenous participation as indigenous sovereignty", where they argue that the recognition of indigenous peoples' rights to consultation and FPIC with respect to matters affecting their property rights to lands 
and natural resources is "an implicit recognition of indigenous sovereignty [over natural resources]". ${ }^{47}$ Thus, it is difficult to draw a clear cut line between indigenous people's right to PSNR and the right to property and associated procedural rights relating to natural resources.

Therefore, it is not useful to emphasize on the strictly Westphalian sense of the term 'sovereignty' when dealing with indigenous peoples' right to PSNR; rather the focus should be on the content of the right itself, in line with the right to internal self-determination. Accordingly, the right of indigenous peoples to PSNR should be understood as empowering them to be holders of, and to include the free disposition of, their natural resources in the sense that they have at their disposal powers of decision-making as to how their natural resources should be utilized. It is in the light of this understanding that the application of the right to PSNR for indigenous peoples will be examined in the next sections.

\subsubsection{Scholarly Views, and Provisions of Indigenous-specific Instruments, on the Application of the Right to PSNR for Indigenous Peoples}

The issue of the application of the right to PSNR for indigenous peoples is subject to opposing views among scholars of international law. Since the right to PSNR deals with the economic dimension of the right to self-determination, all of the arguments against the application of the right to self-determination to indigenous peoples in general (discussed in section 3.1) arise in connection with this debate as well. Duruigbo argues that 'peoples under colonial domination' were the initial subjects of the right to PSNR; and hence the term 'peoples' in the post-colonial period refers only to the entire population of a State. ${ }^{48}$

According to him, the right to PSNR is vested on the whole population of a State and not to any portion of the population, ${ }^{49}$ which in effect excludes indigenous peoples from being the holders of the right. Duruigbo further argues that, while vesting the right to PSNR to the entire population is the most "plausible, realistic and sustainable position" to make claims against the leaders of a State in the event of irresponsible use of resources, vesting the right to PSNR in portions of a population could serve as "a launching pad for secession" ${ }^{50}$ That is, granting a right to PSNR to a portion of the population, such as indigenous peoples, increases threats to the State because of its high potential to reactivate movements for the formation of independent statehood. Therefore, such and other arguments have been used to curtail the application of the right to PSNR for indigenous peoples.

Other scholars argue in favour of the application of the right to PSNR for indigenous peoples. Miranda argues that the right to PSNR is directly applicable to indigenous peoples because "[they] are similarly situated to the colonial peoples to whom the principle originally applied; and as a result, indigenous peoples bear sovereign rights over the land and natural resources that they have traditionally used and occupied" ${ }^{51}$ Miranda further notes:

Like colonial peoples and developing states, indigenous peoples have been subject to an inequitable distribution of developmental gains. In this vein, application of the doctrine of permanent sovereignty over natural resources to indigenous peoples serves as 


\section{E. L. Enyew}

a necessary platform for indigenous peoples' control over the means and goals of their own progress. ${ }^{52}$

Daes follows suit, arguing that despite the absence of classical forms of colonial structures in current times, "indigenous peoples are colonized peoples in the economic, political and historical sense; and that they suffer from unequal economic arrangements in the same way as other colonized peoples [used to suffer]". ${ }^{33}$ Consequently, Daes claims that a modern concept of indigenous self-determination must carry with it the essential right to control and dispose of their natural resources..$^{54}$ Contrary to Duruigbo's view, Daes holds that vesting the right to PSNR on indigenous peoples would not serve as 'a launching pad for secession'. ${ }^{55}$ This is mainly because the right to PSNR for indigenous peoples is exercised through democratic participation consistent with their right to internal self-determination, which does not open for secession. ${ }^{56}$

In addition to scholarly debate, the various substantive and procedural rights of indigenous peoples relating to lands, territories, and natural resources provided in ILO Convention No. 169, the UNDRIP, and ADRIP affirm that indigenous peoples are the "sovereigns" of the natural resources located on and within their lands and territories. These instruments recognize the special relationship of indigenous peoples with their traditionally owned or otherwise occupied and used lands and resources; and impose a corresponding obligation on States to respect the special importance of those lands and resources for their cultures and spiritual values. ${ }^{57}$ These rights over lands and natural resources, inter alia, include the right to own, possess and use, and to participate in the management and conservation of natural resources..$^{58}$

Moreover, the aforementioned indigenous-specific instruments recognize indigenous peoples' procedural rights to be consulted in good faith and to participate in any matters that may affect them, including the right to free, prior and informed consent (FPIC) with respect to measures having a 'significant impact' on natural resources of special significance to indigenous peoples. ${ }^{59}$ These rights affirm that land and natural resources are intrinsic to indigenous peoples and are inherent rights in the sense that no one may take their lands or undertake the exploitation of natural resources found in their traditional lands without expressed consent of the indigenous peoples concerned..$^{60}$ Schrijver, based on his analysis of the provisions of ILO Convention 169 and the then draft UNDRIP, rightly notes that the substantive and procedural "rights of indigenous peoples to the natural resources of their lands are [...] similar to those of States to be derived from the principle of permanent sovereignty over natural resources" ${ }^{61}$ Thus, the aforementioned rights of indigenous peoples are manifestations of their PSNR pertaining to their lands, even though the term permanent sovereignty is not explicitly used by those instruments.

Generally, contemporary developments in international law pertaining to indigenous peoples lead to the conclusion that the right to PSNR is no longer confined to States but also applies to indigenous peoples within the framework of the qualified meaning of the term. Therefore, arguments denying indigenous peoples their right to 
PSNR serve no purpose other than maintaining the "customary international law of indigenous exclusion" 62 thereby legitimatizing States' desire to perpetuate resource exploitation activities in indigenous peoples' lands and territories.

\subsubsection{Indigenous Peoples' Right to PSNR in the Practices of Treaty Bodies}

Various human rights treaty bodies have also affirmed the application of the right to PSNR for indigenous peoples. The practices of the HRC show that indigenous peoples' internal self-determination includes a right to freely dispose of their natural resources as well as the right 'not to be deprived of the means of subsistence' under article 1 of ICCPR. In its 1999 concluding observation on Norway, the HRC expressed its concern over the State party's failure to report on "the Sami people's right to self-determination under article 1 of the Covenant, including paragraph 2 of that article" ${ }^{63}$ Similarly, the HRC criticized Sweden under article 1 of the ICCPR for unduly limiting the role of the Sami Parliament in decision-making processes on issues affecting the traditional lands and economic activities of the indigenous Sami people. ${ }^{64}$ The Committee recommended the State party "take steps to involve the Sami by giving them greater influence in decision-making affecting their natural environment and their means of subsistence" as stipulated under article 1(2) of ICCPR. ${ }^{65}$

In 2016, while requiring further measures to give effect to the Sami peoples' right under article 1, the Committee appreciated the activities that Sweden undertook "to further advancing the interests of the Sami people and to realize their right to selfdetermination", in particular the amendment of its "Constitution...wherein Sami have been explicitly recognized as a people" ${ }^{66}$ In its 2004 concluding observation on Finland, the HRC criticized the State party for its failure to provide "a clear answer concerning the rights of the Sami as an indigenous people...in the light of article 1 of the Covenant" ${ }^{67}$ The Committee further reiterates its concern over the State party's failure to settle the question of the Sami right to land and natural resources ownership and the various public and private uses of land that affect the Sami's traditional means of subsistence, and endanger their traditional culture, way of life and identity. ${ }^{68}$ These observations clearly suggest that the HRC recognizes the Sami indigenous peoples of the Nordic countries as 'peoples' capable of exercising the right to PSNR under article 1 of ICCPR.

The HRC holds a similar view with respect to the right to PSNR for the indigenous peoples of the American Continent. In its 1999 concluding observation on Canada, the HRC explicitly recognized the particular importance of the right to PSNR for aboriginal peoples. The committee emphasized that the right to self-determination of aboriginal peoples "requires, inter alia, that they must be able to freely dispose of their natural wealth and resources and that they may not be deprived of their own means of subsistence (art.1, para. 2)" ${ }^{69}$ It further underlined that "without a greater share of lands and resources, institutions of aboriginal self-government will fail". ${ }^{70}$ The Committee, then, recommends that Canada's "practice of extinguishing inherent aboriginal rights be abandoned as incompatible with article 1 of the Covenant". ${ }^{71}$ 


\section{E. L. Enyew}

The Committee entertained a similar view in its $2006^{72}$ and $2015^{73}$ concluding observations on Canada. Likewise, in its 2006 concluding observation on the USA, the HRC requires the State to "take further steps to secure the rights of all indigenous peoples, under articles 1 and 27 of the Covenant, so as to give them greater influence in decision making affecting their natural environment and their means of subsistence as well as their own culture". ${ }^{74}$ In 2010, the HRC recommends Mexico take all necessary measures to ensure the effective engagement of indigenous peoples for decision-making with respect to all matters affecting their natural resources "in accordance with article 1, paragraph 2 , and article 27 of the Covenant". ${ }^{75}$

On the continent of South America, the HRC recommends Chile "make every possible effort to ensure that its negotiations with indigenous communities lead to a solution that respects the land rights of these communities in accordance with article 1, paragraph 2, and article 27 of the Covenant" ${ }^{76}$ With respect to other South American States, the HRC does not directly address indigenous peoples' right to PSNR by invoking article 1 ; but rather in terms of their right to the material basis of culture under article $27 .{ }^{77}$

The HRC has also invoked article 1 (2) in embracing the right to PSNR for the aboriginal peoples of Australia. In its 2000 concluding observations, the Committee criticized Australia for not taking sufficient action to protect indigenous peoples' right to PSNR and calls upon the State to "take the necessary steps in order to secure for the indigenous inhabitants a stronger role in decision-making over their traditional lands and natural resources (art. 1, para. 2)" ${ }^{78}$ Therefore, even though it has been reluctant to accept individual communications on indigenous peoples' right to PSNR under the Optional Protocol to ICCPR for jurisdictional reasons, the HRC clearly endorses this right by invoking article 1(2) in its concluding observations in a number of State reports.

The Committee on Economic, Social and Cultural Rights (CESCR) has also evolutively interpreted the right to PSNR incorporated under article 1(2) of the ICESCR to embrace indigenous peoples. Affirming that the Sami people are holders of the right to PSNR under article 1, the Committee urged Finland to "strengthen its efforts to adopt the necessary legislative and administrative measures to fully and effectively guarantee the Sami people's right to own their land and to freely dispose of their natural wealth and resources" ${ }^{79}$ In its 2015 concluding observation on Paraguay, the Committee expressed its concern that "the State party has not yet legally recognized the right of indigenous peoples to dispose freely of their natural wealth and resources or put in place an effective mechanism to enable them to claim their ancestral lands (art. 1)" ${ }^{80}$ The Committee, then, urged Paraguay to adopt appropriate measures to enable indigenous peoples to "exercise their right to dispose freely of their lands, territories and natural resources". ${ }^{81}$ Similarly, in its 2015 concluding observation on Chile, the CESCR criticized the State party for "the limited protection of the right of indigenous peoples to dispose freely of their wealth and natural resources and of their ancestral lands (art. 1)". ${ }^{82}$ The Committee required the State party to "increase 
its efforts to guarantee the right of indigenous peoples to dispose freely of their lands, territories and natural resources, by such means as providing legal recognition and the necessary legal protection". ${ }^{83}$ Hence, even though the complaint procedure under the Optional Protocol to ICESCR is yet to produce a concrete jurisprudence, the CESCR has affirmed the right to PSNR for indigenous peoples in its practice of monitoring States' reports.

Relatively recent case law has also confirmed that indigenous peoples are holders of the right to PSNR. In the case of Endorois v. Kenya, the African Commission on Human and Peoples' Rights explicitly affirms indigenous peoples' right to PSNR as stipulated under Article 21 of African Charter on Human and Peoples' Rights. The African Commission decided that "the Endorois have the right to freely dispose of their wealth and natural resources in consultation with the respondent State" ${ }^{84}$ The decision explicitly uses the expression "the right to freely dispose of their wealth and natural resources" verbatim as used in common article 1 of the twin human rights conventions, and article 21 of the African Charter on Human and Peoples' Rights. Similarly, in the case of African Commission on Human and Peoples'Rights v. Kenya, the African Court of Human and Peoples' Rights (ACtHPR) found Kenya in violation of the Ogiek indigenous peoples' right to PSNR as incorporated under article 21 of the Charter. The Court held that, by evicting the communities from their ancestral lands, Kenya "has violated article 21 of the Charter since the Ogieks have been deprived of the right to enjoy and freely dispose of the abundance of food produced by their ancestral lands". ${ }^{85}$ These recent decisions provide additional evidence showing the trend toward a recognition of the application of the right to PSNR for indigenous peoples by regional human rights bodies.

In summary, the short review above, though not exhaustive, shows that global and regional human rights bodies have increasingly accepted indigenous peoples as subjects of the right to PSNR by proactively interpreting the relevant provisions contained in their respective instruments. They have adapted the right to PSNR to the specific situation of indigenous peoples, and have embraced it in contemporary developments in international law pertaining to indigenous peoples. This approach is consistent with the view that the human rights of indigenous peoples derive from the whole corpus of human rights instruments, including both general global and regional human rights instruments and human rights instruments specific to indigenous peoples. As such, the treaty bodies have affirmed that indigenous peoples' right to PSNR should be interpreted in the same manner as the right to PSNR that other peoples have under international law. Denying indigenous peoples the right to freely dispose of their natural resources, while allowing all other peoples the same right, is contrary to the principle of equality and non-discrimination.

\subsubsection{Which Natural Resources do Indigenous Peoples have Permanent Sovereignty Over?}

The above section concludes that indigenous peoples are currently recognized as subjects of the right to PSNR; but the nature and type of resources over which they 


\section{E. L. Enyew}

exercise sovereignty is not clearly identified. This section provides a general delimitation of the nature and type of these resources. The rights of indigenous peoples to the natural resources pertaining to their lands (both surface and sub-surface resources) are specifically provided under Article 15 of ILO Convention No. 169. Article 15 states: ${ }^{86}$

1. The rights of the [indigenous] peoples concerned to the natural resources pertaining to their lands shall be specially safeguarded. These rights include the right of these peoples to participate in the use, management and conservation of these resources.

2. In cases in which the State retains the ownership of mineral or sub-surface resources or rights to other resources pertaining to lands, governments shall establish or maintain procedures through which they shall consult these peoples, with a view to ascertaining whether and to what degree their interests would be prejudiced, before undertaking or permitting any programmes for the exploration or exploitation of such resources pertaining to their lands. The peoples concerned shall wherever possible participate in the benefits of such activities, and shall receive fair compensation for any damages which they may sustain as a result of such activities.

The Convention provides a special safeguard to the rights of indigenous peoples "to the natural resources pertaining to their lands", but does not define the term "natural resources". The ordinary meaning of the expression "natural resources pertaining to their lands" may be understood to refer to all natural resources, both surface and sub-surface, located on or within all lands ${ }^{87}$ and territories which indigenous peoples have ownership, possession, and use rights acquired through traditional ownership, traditional occupation, or traditional use. ${ }^{88}$ For example, in the case of Saramakav. Suriname, the Saramaka people argued that their right to use and enjoy all natural resources that lie on and within their lands is a necessary condition for their existence as a people. ${ }^{89}$ Accordingly, they claimed that they have a right "to own everything, from the very top of the trees to the very deepest place that you could go under the ground". ${ }^{90}$ Thus, in principle, indigenous peoples claim to have sovereign rights over all natural resources located on their traditional lands according to a broader understanding of the term 'land'.

Nonetheless, indigenous peoples' sovereign rights over their natural resources manifests differently depending on the type of resource. In other words, the nature and type of resource is a relevant consideration in determining the extent of sovereign rights indigenous peoples have over these resources. Hence, some general considerations must be taken into account in determining the scope and extent of indigenous peoples' rights to PSNR pertaining to their lands.

Firstly, whether the resource is culturally relevant to indigenous peoples or not is the main criterion. Resources culturally relevant to indigenous peoples are those resources 
to which indigenous peoples have a traditional attachment, in the sense that "they have historically held or enjoyed the incidents of ownership; namely, use, possession, control, and right of disposition". ${ }^{91}$ These are resources that indigenous peoples have traditionally used for their subsistence, cultural and religious activities. In Saramaka people v. Suriname, the Inter-American Court of Human Rights (IACtHR) concluded that in the context of indigenous and tribal communities "the right to use and enjoy their territory would be meaningless [...] if said rights were not connected to the natural resources that lie on and within the land". ${ }^{92}$ The Court further stressed that natural resources that need special protection are "those natural resources traditionally used and necessary for the very survival, development and continuation of such peoples' way of life"..$^{93}$ In the case of Endorois v. Kenya, the African Commission on Human and Peoples' Rights concurs with the IACtHR's conclusion in identical terms. ${ }^{94}$ These types of resources are related to the specific cultural situations of indigenous peoples and vary depending on the cultures and local circumstances of the indigenous peoples concerned. As regards the extent of rights over culturally relevant resources, the IACtHR concluded that the right to enjoy traditionally owned lands necessarily implies a similar right with regard to natural resources traditionally used by, and necessary for the survival of, indigenous communities. ${ }^{95}$

Likewise, Åhrén argues that "to the extent an indigenous community has traditionally used natural resources situated on or within its traditional territory, the community must reasonably hold the same right over such resources as it does with regard to the land area as such". ${ }^{96}$ This implies that indigenous peoples have full permanent sovereign right over culturally relevant natural resources found within the lands and territories they have traditionally owned or occupied. Their rights are not only limited to the right to "participate in the use, management and conservation of the resources" as stipulated under article 15(1) of ILO Convention No. 169, but also include full rights to dispose freely of natural resources.

Secondly, a distinction should also be drawn between surface and sub-surface resources. Many States maintain the position that they retain ownership over sub-surface resources. ${ }^{97}$ Ulfstein argues that the rights of indigenous peoples to exploit and dispose of sub-surface resources pertaining to their lands may be restricted because ownership of those resources is reserved for the State, which uses them to provide for the public welfare. ${ }^{98}$ This implies that a State has a legal right to decide and grant licenses for the exploration and exploitation of mineral and other sub-surface resources found in indigenous peoples' lands and territories, as well as to collect the revenues. However, such a restrictive interpretation is subject to a general consideration as to whether the sub-surface natural resource in question is culturally relevant for indigenous peoples, or not, as pointed out earlier. If the sub-surface resources are culturally relevant for indigenous peoples, they, instead of the State, have sovereign right over those resources. ${ }^{99}$ The hesitant formulation evident in the expression "[i] $n$ cases in which the State retains the ownership of mineral or sub-surface resources [...]" in article 15(2) of ILO Convention No. 169, suggests that States do not always have automatic ownership rights over all sub-surface resources located in indigenous 


\section{E. L. Enyew}

peoples' lands. The implication is that there are some sub-surface resources where indigenous peoples are the ultimate owners. These sub-surface resources include, inter alia, those resources that are culturally relevant to indigenous peoples, as discussed above. Hence, if a resource is culturally relevant to and traditionally used, indigenous peoples' sovereignty over that resource may be expressed by exercising full ownership rights regardless of whether it occurs above- or sub-surface.

Moreover, despite the priority of international law on the protection of culturally relevant and traditionally used natural resources, indigenous peoples also have certain sets of rights with respect to non-culturally relevant sub-surface resources located on their traditional lands and territories. ILO Convention No. 169 provides those sets of rights under Article 15(2). First, indigenous peoples have the right to be consulted before the government undertakes or permits any programs for the exploration or exploitation of sub-surface natural resources. This right goes beyond consultation and includes the right to free, prior and informed consent (FPIC) if the sub-surface resource extraction project involves the eviction of indigenous peoples from their lands pursuant to Art. 16 ILO Convention and Art. 10 of UNDRIP; or if it disposes hazardous waste on their territories according to Art. 29 UNDRIP. With respect to other matters, the issue of whether indigenous peoples' FPIC is required in sub-surface resource extraction projects will be determined on a case-by-case basis depending on the extent of its impact on their identity and survival as indigenous peoples. ${ }^{100}$ Secondly, if the sub-surface resources extraction project is permitted, article 15(2) of the ILO Convention still guarantees other sets of rights, including the right to participate in the benefits resulting from the exploitation and use of natural resources, and a right to receive fair compensation for any damages caused as a result of the extraction activities. This way the Convention tries to balance the interests of States and indigenous peoples by recognizing the ownership rights of States over non-culturally relevant sub-soil resources, while at the same time granting indigenous peoples certain rights relating to those resources.

In conclusion, the nature and type of resource determines the extent to which indigenous peoples possess sovereign rights over natural resources. While current international law and jurisprudence support full PSNR with respect to natural resources which are traditionally used or culturally relevant, with respect to natural resources which are not traditionally used, PSNR is expressed in terms of consultation (which may include FPIC), participation in benefit sharing, and payment of compensation in the event of damage.

\section{Exercise of Indigenous Peoples' Right to PSNR in the Context of Cross- border Resource Management}

\subsection{Generally on Indigenous Peoples' Cross-border Cooperation}

Indigenous peoples' right to internal self-determination is subject to broad interpretation, and includes not only their right to be represented in international organizations 
and to participate in various international meetings, but also their right to freely maintain and develop relations with the international community across borders. ${ }^{101}$ This is clearly recognized under Article 36 (1) of UNDRIP, which states that "indigenous peoples, in particular those divided by international borders, have the right to maintain and develop contacts, relations and cooperation, including activities for spiritual, cultural, political, economic and social purposes, with their own members as well as other peoples across borders".

Article 32 of ILO Convention No. 169 also contains a similar provision, stating that " [g] overnments shall take appropriate measures, including by means of international agreements, to facilitate contacts and cooperation between indigenous peoples across borders, including activities in the economic, social, cultural, spiritual and environmental fields". Both instruments emphasize the economic aspect of cross-border cooperation. Thus, consistent with the broader understanding of internal self-determination, the right to PSNR of indigenous peoples includes a right to develop cooperation with their own members and other peoples across national borders to deal with matters affecting their natural resources. The following sections discuss some practical examples of the application of indigenous peoples' right to PSNR in cross-border resource management and use. The aim is not to provide a detailed account of State practices, but rather to point out the existence of such practices.

\subsection{Management Agreements of the Inuit of Canada, US and Greenland}

Certain practices of the exercise of the right to PSNR by indigenous peoples exist in the context of cross-border resource management. The Inuvialuit-Inupiat Polar Bear Management Agreement in the Southern Beaufort Sea is the first clear example. ${ }^{102}$ This is an agreement entered into by two Inuit indigenous groups -the Inuvialuit of Canada and Inupiat of Alaska -without the involvement of their respective States, for the conservation and management of polar bears, which are subject to shared harvest by the two groups in the southern Beaufort Sea. The main objectives of the agreement are to ensure the perpetual maintenance of the sustainable harvest of polar bears by the two peoples through sound conservation strategies, ${ }^{103}$ and to facilitate the cultural exchange of polar bear meat and products between traditional users in Alaska and Canada. ${ }^{104}$ The agreement establishes a joint commission, consisting of representatives from the Inuvialuit and Inupiat, mandated to determine the annual sustainable harvest of polar bears and to divide the quota between the two indigenous groups. ${ }^{105}$ The fact that the respective governments have acquiesced to the agreement and do not object to the management practices of the two indigenous groups ${ }^{106}$ implies that they have accepted it as legally binding bilateral treaty, having equal force as that concluded between sovereign States.

The 2009 Tripartite Memorandum of Understanding for the Conservation and Management of Polar Bear Populations is another case where indigenous peoples have exercised their right to PSNR. ${ }^{107}$ This tripartite agreement (between the government of Canada, the government of Nunavut, and the government of Greenland) 


\section{E. L. Enyew}

concerns the conservation of Polar Bears in Kane Basin and Baffin Bay, where Inuit from both Nunavut and Greenland have traditionally harvested polar bears for their dietary, cultural and economic needs. The agreement establishes a joint commission, including representatives from both groups, which is empowered to make recommendations concerning the total harvest of polar bears in the area and the allocation of quotas between Greenland and Nunavut. ${ }^{108}$ Inuit representatives from both countries were involved in the making of the agreement as well as in the decision-making body established by the agreement, the joint commission, as equal parties to their States.

Generally, the Inuit indigenous peoples (in both agreements) perform such cross-border resource conservation and management activities as holders of sovereign rights over their traditionally used natural resources. This understanding is clearly stipulated in the Circumpolar Inuit Declaration on Sovereignty in the Arctic. It declares that the Inuit of the Arctic are equal and active partners of their respective States. ${ }^{109}$ The Declaration further declares that "the inextricable linkages between issues of sovereignty and sovereign rights in the Arctic and Inuit self-determination and other rights require States to accept the presence and role of Inuit as partners in the conduct of international relations in the Arctic", ${ }^{110}$ including their active and equal partnership in policy and decision making in resource development initiatives. ${ }^{111}$ Hence, the right to PSNR allows the Inuit indigenous peoples to have "equal power" with their own States when dealing with issues that may affect their natural resources related rights.

\subsection{Management Agreements of Nordic Countries and the Indigenous Sámi}

The Sámi people, whose traditional homeland spans four states; the three Nordic States (Norway, Sweden and Finland), and the Kola Peninsula of the Russian Federation, could be expected to provide us with successful examples of cross-border cooperation between indigenous peoples regarding the management of natural resources. Unfortunately, this is currently not the case; previous bilateral cross-border agreements on reindeer husbandry and migration, and the use of pastures and other renewable natural resources in neighbouring countries have now been discontinued as a result of disagreements. These customary based rights were originally regulated in the Lapp Codicil of 1751, a bilateral agreement signed as an annex to the border agreement between Norway and Sweden from the same year, ${ }^{112}$ and followed by subsequent conventions signed by the two countries. The disagreements, which prevented the renegotiation of the Convention in 2005, and which prompted Norway to adopt its own law, ${ }^{113}$ are due to both internal disputes between Sámi on each side of the State boundaries, and between Norway and Sweden.

In addition, a Nordic Sami Convention, which can be viewed as a successor to the Codicil; but with a broader focus than reindeer husbandry, has been in the negotiation process for more than ten years. ${ }^{114}$ The three Sami Parliaments have been actively involved in the drafting process of the Convention as equal parties with their 
States. The parties negotiating the proposed convention, which includes provisions on the management of natural resources, have not yet succeeded in reaching agreement. However, the three Nordic governments managed to reach agreement on 13 January $2017 .{ }^{115}$ Yet, there are still disparate opinions in the three countries' Sámi parliaments regarding whether they will endorse the text of the Convention or not. Adopted in the form presented by the three state governments, article 32 states:

In view of the fact that Sami's rights to land and water are of particular importance for the conservation of the Sámi culture, language and society, states and others who administer state property should consult as far as possible or otherwise actively involve the Sami in questions about the management of natural resources affecting the Sámi and not covered by the requirements of Article 17. ${ }^{116}$

In addition, Article 26 regulates cross-border cooperation with respect to matters of special importance for the Sami culture, including the management of natural resources. Consensus on the convention text is expected to emerge, which will mean that the Sami will control and dispose of their own natural resources to a greater extent than previously, both internally in the Nordic countries and in cross-border cooperation.

Within the Sámi traditional areas, another case warrants closer scrutiny. On the one hand, it illustrates a conflict, but on the other hand, cooperation. The case concerns management of the Tana River, the largest salmon river in the Sámi area by catch, and also the best salmon river in Norway and Finland. Indigenous peoples on both sides of the country borders are in a legal dispute with authorities over the regulation of fishing. Representatives from Sámi organizations are fighting to continue their traditional practice of fishing with nets, while the government authorities want to prohibit this practice in order to conserve fish stocks, but paradoxically promoting sport fishing.

The legal sides of the conflict deal with the fact that the state authorities failed to comply with their consultation obligations to the Sámi under ILO 169 article 6, and instead negotiated bilaterally over their heads, and on that basis signed an agreement on the regulation of the salmon resources. ${ }^{117}$ In addition, it can be argued that the obligation to obtain free, prior and informed consent from representative Sámi bodies over the regulation of salmon resources, which is rooted in UNDRIP article 19, has not been emphasized. It can further be argued that an intervention that impacts such an important natural resource for the Sámi, and which also constitutes a material basis for the right of the Sámi to enjoy their culture, violates Article 27 of the ICCPR. The two Nordic countries should have followed the example of the Polar bear management agreements of the Inuit of Canada, US and Greenland (discussed above) and involved the Sami indigenous peoples in the process of reaching the salmon management bilateral treaty. Eventually, if the agreement, signed by Norway and Finland 30 September 2016 and recently approved by the respective parliaments of these two countries, is found to violate these international rules, it will probably be resolved in the courts since local Sámi organizations have announced that they will bring it to court. ${ }^{118}$ 


\section{E. L. Enyew}

\section{Conclusion}

Unlike a strict Westphalian understanding, sovereignty in contemporary times is regarded as a compound doctrine that encompasses the sovereignty of a State and the sovereignty of peoples. ${ }^{119}$ The right to PSNR is a clear manifestation of the compound nature of the right to sovereignty where both States and "all peoples" are the right holders. Having initially emerged as a right of peoples under colonial domination and newly independent developing States, the right to PSNR has further developed as a right of 'all States' regardless of their economic status. With the development of human rights instruments, the right to PSNR has further evolved from a right of States to a human right of "all peoples". This article examines the question of whether indigenous peoples are subjects of the right to PSNR by virtue of their being "peoples" within the meaning of international law. The article concludes in the affirmative based on an analysis of contemporary international law pertaining to indigenous peoples, practices of relevant treaty monitoring bodies, and an assessment of certain State practices in cross-border natural resource use.

The analysis shows that the right to PSNR is evolutionary and capable of accommodating different subjects from time to time, according to the needs of the international community and developments in international law. Several developments have taken place in international law pertaining to indigenous peoples since the inception of the right to PSNR in the 1950s. In line with such legal developments, indigenous peoples are currently recognized as "peoples" capable of exercising the right to internal self-determination, which includes the right to dispose freely of natural resources. The initial objectives of the right to PSNR - a demand from colonial peoples to control their natural resources in order to promote their wellbeing and to satisfy their subsistence needs, and to curtail irresponsible exploitation of natural resources by colonial powers - fits perfectly with the current claims of indigenous peoples to exercise control over, and freely dispose of, their natural resources. Moreover, the right to PSNR allows indigenous peoples to have a strong say with respect to matters affecting their lands and natural resources as a result of oppressive arrangements, contracts or concessions granted by States. ${ }^{120}$ It gives indigenous peoples the status to enter into treaty agreements with their States, or other peoples across national borders, concerning any resource development activities on their lands and territories. The right to PSNR also signifies a recognition of the right of indigenous peoples "to have 'a seat at the table' when international bodies are addressing resource related issues that are of concern to [them]". ${ }^{121}$ Hence, a right that originally emerged to facilitate the end of economic colonization must also work to decolonize the "customary international law of indigenous exclusion". ${ }^{122}$

To sum up, indigenous peoples' right to PSNR is an essential umbrella human right. Any undermining of indigenous peoples' right to PSNR constitutes a threat to other fundamental human rights incorporated in the major human rights covenants. Hence, States should recognize and protect indigenous peoples' right to PSNR by taking appropriate measures, including the unequivocal incorporation of this right 
into their national laws and policy directives. States should also adopt proper approaches and legal arrangements to facilitate the implementation of indigenous peoples' right to PSNR both within and across national borders.

\section{ACKKNOWLEDGEMENTS}

The author would like to thank Prof. Øyvind Ravna, UiT -The Arctic University of Norway, for his technical help in restructuring the article in general and for his enormous guidance and contribution to section 4.3 (on the Nordic Sámi issues) of the article in particular; and to Prof. Nigel Banks, University of Calgary and KG Jebsen Centre UiT, for his constructive comments on an earlier version of the manuscript. The author also extends his gratitude to the publication fund of UiT-The Arctic University of Norway for covering the publication charges of the article.

\section{NOTES}

1. UNGA Res. 1803(XVII), Permanent Sovereignty over Natural Resources (1962), para. 1; International Covenant on Civil and Political Rights, 999 UNTS 171 (1966), art. 1(2); International Covenant on Economic, Social and Cultural Rights, 993 UNTS 3 (1966), art. 1(2).

2. Alice Farmer, "Towards a Meaningful Rebirth of Economic Self-determination: Human Rights Realization in Resource-Rich Countries”, fournal of International Law and Politics 39 (2006): 421.

3. Ibid, 418; UNGA Res. 1803(n 1), para. 1.

4. Nico J. Schrijver, Sovereignty over Natural Resources: Balancing Rights and Duties (Cambridge University Press, 1997), 36.

5. UNGA Res. 3281 (XXIX), Charter of Economic Rights and Duties of States (1974), Art. 2(2)(b).

6. Schrijver (n 4), 3 .

7. Anthony Anghie, Imperialism, Sovereignty and the Making of International Law (Cambridge University Press, 2004), 211.

8. Ibid, 211.

9. Schrijver (n 4), 3 .

10. Ibid.

11. Ricardo Pereira and Orla Gough, "Permanent Sovereignty over Natural Resources in the $21^{\text {st }}$ Century: Natural Resource Governance and the Right to Self-determination of Indigenous Peoples under International Law", Melborne fournal of International Law 14 (2013): 5.

12. Angie (n 7), 213.

13. Ibid.

14. UNGA Res. 1803(n 1), preambular para. 4 (emphasis added).

15. UNGA Res. 3281(n 5), Art. 2(1).

16. UNGA Res. 3016 (XXVII), Permanent Sovereignty over Natural Resources of Developing Countries (1972).

17. UNGA Res. 3171 (XXVIII), Permanent Sovereignty over Natural Resources (1973).

18. United Nations Convention on the Law of the Sea (LOSC), 1833 UNTS 3 (1982).

19. Convention on Biological Diversity, 1760 UNTS 79 (1992), Art.3.

20. Lillian A. Miranda, "The Role of International Law in Intrastate Natural Resource Allocation: Sovereignty, Human Rights and Peoples-Based Development”, Vanderbilt Fournal of Transnational Law 45 (2012): 798.

21. George Elian, The Principle of Sovereignty over Natural Resources (Sijthoff \& Noordhoff, 1979), 12.

22. LOSC (n 18), Art.2.

23. UNGA Res. 1803(n 1), para.1.

24. Farmer (n 2), 427.

25. ICCPR and ICESCR (n 1), art. 1(2) (emphasis added). 
26. ICCPR, Art.47; ICESCR, Art. 25.

27. African Charter on Human and Peoples' Rights, 1520 UNTS 217 (1981), Art.20.

28. Ibid., Art. 21(1) (emphasis added).

29. Ibid.

30. Ibid., Art. 21(2).

31. Angie (n 7), 32 .

32. Karen Knop, Diversity and Self-determination in International Law (Cambridge University Press: 2002), 58; Richard N. Kiwanuka, "The Meaning of 'peoples' in the African Charter on Human and Peoples' Rights", The American fournal of International Law 82, 1(1988).

33. Farmer (n 2), 421.

34. Alexandra Xanthaki, Indigenous Rights and United Nations Standards: Self-determination, Culture and Land (Cambridge University Press, 2007), 146.

35. Farmer (n 2), 440 .

36. It is worth mentioning here that, despite the absence of express provision on self-determination in the ILO Convention No. 169, the International Labour Office in its commentary makes it clear that the Convention places no limitation on the right of indigenous peoples to internal self-determination. The Labour Office further notes that the "Convention is compatible with any future international instruments which may establish or define the right to self-determination of indigenous peoples" (See International Labour Office, ILO Convention on Indigenous and Tribal Peoples, 1989 (No.169): A manual (Geneva, 2003), 9).

37. United Nations Declaration on the Rights of Indigenous Peoples, UNGA Res. $61 / 295$ (13 Sept. 2007), Arts. 4 \& 46; American Declaration on the Rights of Indigenous Peoples, AG/Res. 2888 (XLVI-O/16), (15 June 2016), Arts.4 \& 21(1).

38. See James Anaya. "The Right of Indigenous Peoples to Self-determination in the Post-Declaration Era”, in Making the Declaration Work: the UN Declaration on the Rights of Indigenous Peoples, ed. Charters C. and Stavenhagen R. (Copenhagen: 2009); Mattias Åhrén, Indigenous Peoples'Status in the International Legal System (Oxford University Press, 2016).

39. The details of the Committees' observations are discussed in the next section in order to avoid repetition.

40. Miranda (n 20), 808.

41. Erica-Irene A. Daes, “Indigenous Peoples’ Permanent Sovereignty over Natural Resources”, UN Doc. E/ CN.4/Sub.2/2004/30 (Final Report to the Commission on Human Rights, 13 July 2004), para.18.

42. Ibid.

43. Erica-Irene A. Daes. "Indigenous Peoples' Rights to Land and Natural Resources", in Minorities, Peoples and Self-determination, ed. Nazila Ghanea and Alexandra Xanthaki (Martinus Nijhoff Publishers, 2005), 87.

44. Richard Barnes, Property Rights and Natural Resources (Hart Publishing, 2009).

45. Pereira and Gough (n 11), 1 .

46. Daes (n 41), para. 40 (emphasis added).

47 . Evan Fox-Decent and Ian Dahlman, "Sovereignty as Trusteeship and Indigenous Peoples", Theoretical Inquiries in Law 16, 2 (2015): 518, 532.

48. Emeka Duruigbo, "Permanent Sovereignty and Peoples' Ownership of Natural Resources in International Law", The George Washington International Law Review 38 (2006): 52.

49. Ibid, 54 .

50. Ibid, 56 .

51. Miranda (n 20), 807.

52. Ibid.

53. Daes (n 41), para.32.

54. Ibid, para.17.

55. Ibid.

56. Farmer (n 2), 421; Dorothée Cambou and Stefaan Smis, "Permanent Sovereignty over Natural Resources from a Human Rights Perspective: Natural Resources Exploitation and Indigenous Peoples' Rights in the Arctic", Michigan State International Law Review 22, 1 (2013): 350.

57. ILO Convention Concerning Indigenous and Tribal Peoples in Independent Countries, 1650 UNTS 383 (1989), Art.13 (1); UNDRIP (n 36), Art.25; ADRIP (n 36), Art. 25(1).

58. Ibid, Arts.14 \& 15; UNDRIP, Art.26; ADRIP, Art.25 (3). 
59. Ibid, Arts.6, 7, 15; UNDRIP, Arts.18, 19. See also Expert Mechanism Advice No. 2(2011), "Indigenous peoples and the right to participate in decision-making”, UN Doc. A/HRC/18/42, para. 22; HRC, Ángela Poma Poma v. Peru, UN Doc. CCPR/C/95/D/1457/2006 (2009), para.7.6.

60. Allison M. Dussias, "Spirit Food and Sovereignty: Pathways for Protecting Indigenous Peoples' Subsistence Rights", Cleveland State Law Review 58 (2010): 340.

61. Schrijver (n 4), 318. See also Siegfried Wiessner, "Indigenous Sovereignty: A Reassessment in Light of the UN Declaration on the Rights of Indigenous Peoples", Vanderbilt Fournal of Transnational Law 41 (2008).

62. Bartolomé Clavero, "The Indigenous Rights of Participation and International Development Policies", Arizona fournal of International and Comparative Law 22, 1 (2005): 43.

63. HRC, Concluding Observation: Norway, UN Doc. CCPR/C/79/Add. 112 (1999), para.17.

64. HRC, Concluding Observation: Sweden, UN Doc. CCPR/CO/74/SWE (2002), para.15.

65. Ibid.

66. HRC, Concluding Observation: Sweden, UN Doc. CCPR/C/SWE/CO/7 (2016), paras. 38 \& 39.

67. HRC, Concluding Observation: Finland, UN Doc. CCPR/CO/82/FIN (2004), para.17.

68. Ibid; HRC, Concluding Observation: Finland, UN Doc. CCPR/C/FIN/CO/6 (2013), para.16.

69. HRC, Concluding Observation: Canada, UN Doc. CCPR/C/79/Add.105 (1999), para.8.

70. Ibid.

71. Ibid.

72. HRC, Concluding Observation: Canada, UN Doc. CCPR/C/CAN/CO/5 (2006), paras.8 \& 9.

73. HRC, Concluding Observation: Canada, UN Doc. CCPR/C/CAN/CO/6 (2015), para.16.

74. HRC, Concluding Observation: United States of America, UN Doc. CCPR/C/USA/CO/3/Rev.1 (2006), para.37.

75. HRC, Concluding Observation: Mexico, UN Doc. CCPR/C/MEX/CO/5 (2010),para. 22.

76. HRC, Concluding Observation: Chile, UN Doc. CCPR/C/CHL/CO/5 (2007), para.19.

77. HRC, Concluding Observation: Nicaragua, UN Doc. CCPR/C/NIC/CO/3 (2008), para. 21; HRC, Concluding Observation: Peru, UN Doc. CCPR/C/PER/CO/5 (2013), para. 24; HRC, Concluding Observation: Belize, UN Doc. CCPR/C/BLZ/CO/1 (2013), para. 25; HRC, Concluding Observation: Paraguay, UN Doc. CCPR/C/PRY/CO/3 (2013), para. 27; HRC, Concluding Observation: Suriname, UN Doc. CCPR/C/SUR/CO/3 (2015), paras. $47 \& 48$.

78. HRC, Concluding Observation: Australia, UN Doc. A/55/40, vol. I (2000), paras.506 \& 507.

79. CESCR, Concluding Observation: Finland, UN Doc. E/C.12/FIN/CO/6 (2014), para.9 (a) (emphasis added).

80. CESCR, Concluding Observation: Paraguay, UN Doc. E/C.12/PRY/CO/4 (2015), para.6.

81. Ibid, para.6 (b).

82. CESCR, Concluding Observation: Chile, UN Doc. E/C.12/CHL/CO/4 (2015), para.8.

83. Ibid, para. 8 (c).

84. Endorois Welfare Council v. Kenya [2009] AfComHPR, communication No. 279/2003, para.268.

85. African Commission of Human and Peoples' Rights v. Republic of Kenya (the Ogiek Case) [May 2017] ACtHPR, Application No. 006/2012, Judgement on the Merit, paras. 201 \& 227.

86. ILO Convention No. 169 (n 57), Art. 15.

87. Indigenous peoples" "land" is broadly defined to "include the concept of territories, which covers the total environment of the areas which the [indigenous] peoples concerned occupy or otherwise use" (ILO Convention No. 169, Art. 13(2)).

88. Daes (n 43), 88 .

89. Saramaka People v. Suriname (Preliminary Objections, Merits, Reparations and Costs), IACtHR, Case No.172 [2007], para.118.

90. Ibid, para.119.

91. Daes (n 43), 88.

92. Saramaka v. Suriname (n 86), para.122.

93. Ibid, para. 122.

94. Endorois v. Kenya (n 84), para.261.

95. Saramaka v. Suriname (n 89), paras. $121 \& 141$.

96. Åhrén (n 38), 213. It is important to acknowledge here that Åhrén uses the language of 'property' instead of PSNR; but the two concepts overlap and the right to property is a manifestation of the right to PSNR (see section 3.2.1). 
97. Geir Ulfstein, “Indigenous Peoples' Right to Land”, Max Planck Yearbook of United Nations Law 8 (2004): 31 .

98. Ibid.

99. Åhrén notes that "some indigenous peoples have a long tradition of using sub-surface, and perhaps in particular sub-soil, resources"; and these resources deserve equal protection as "resources traditionally used" (Åhrén (n 38), 214).

100. The jurisprudence of treaty monitoring bodies and human rights courts have clearly followed this approach. See for example, Ángela Poma Poma v. Peru (n 59), para.7.6; Saramaka v. Suriname (n 89), paras. 134, 137; Endoroisl v. Kenya (n 84), para. 226; Expert Mechanism Advice No. 2(2011): Indigenous peoples and the right to participate in decision-making, UN Doc. A/HRC/18/42, para. 22.

101. Martin Scheinin. "Sami Self-determination: A Nordic perspective of indigenous peoples right to selfdetermination", in Sami Self-determination: Scope and implementation, ed. Henriksen John B., Galdu Cala: fournal of Indigenous Peoples Right No. 2 (2008): 61.

102. The Inuvialuit-Inupiat Polar Bear Management Agreement in the Southern Beaufort Sea (4 March 2000), http://pbsg.npolar.no/en/agreements/USA-Canada.html (Accessed 07 June 2017).

103. Ibid, preambular para.3.

104. Ibid, Art. 2(h).

105. Ibid, Art. 3(d).

106. Byers, Michael, International Law and the Arctic (Cambridge University press, 2013), 174.

107. Memorandum of Understanding between the Government of Canada, the Government of Nunavut, and the Government of Greenland for the Conservation and Management of Polar Bear Populations (2009), http://pbsg.npolar.no/export/sites/pbsg/en/docs/GN-MOU-PB.pdf(Accessed 07 June 2017).

108. Ibid, Art. $4(\mathrm{~g})$.

109. A Circumpolar Inuit Declaration on Sovereignty in the Arctic (Inuit Circumpolar Council, 2009), Art.3.3.

110. Ibid.

111. A Circumpolar Inuit Declaration on Resource Development Principles in Inuit Nunaat (Inuit Circumpolar Council, 2011), Art.4.1.

112. Otto Jebens, "Sami Rights to Land and Water in Norway", Nordic fournal of International Law 55 (1986): 46; Else G. Broderstad, "Cross-border Reindeer Husbandry: Between Ancient Usage Rights and State Sovereignty”, in The Proposed Nordic Saami Convention: National and International Dimensions of Indigenous Property Rights, ed. Bankes N. and Koivurova T. (Hart Publishing, 2013), 149 -174. It is important to mention here that the Lapp Codicil is an important source of law having relevance in the present day, as it has not been repealed.

113. Act on Swedish reindeer husbandry in Norway and Norwegian reindeer husbandry in Sweden (the border reindeer husbandry law), 17 June 2005 no. 100. See also the preparatory works Ot.prp.nr.75 (2004-2005) Om lov om endringer i lov 9. juni $1972 \mathrm{nr} .31$ om reinbeiting i henhold til konvensjon av 9. februar 1972 mellom Norge og Sverige om reinbeite.

114. For an excellent discussion of the negotiation process and contents of the earlier version of the Draft Convention, see Timo Koivurova, "The Draft for a Nordic Sami Convention", European Yearbook of Minority Issues 6 (2007), 103-136; Øyvind Ravna, "The Draft Nordic Saami Convention and the Assessment of Evidence of Saami Use of Land", in The Proposed Nordic Saami Convention: National and International Dimensions of Indigenous Property Rights, ed. Bankes N. and Koivurova T. (Hart Publishing, 2013), 177 -205.

115. iRegjeringen.no: 'Nordisk Samekonvensjon', https:/www.regjeringen.no/contentassets/eac999412c5a4fd083fa35f6e6c7380b/nordisk-samekonvensjon-norsk.pdf (Accessed 07 July 2017). See also The Barents Observer, Historic Sámi agreement: https:/thebarentsobserver.com/en/2017/01/historic-sami-agreement-starts-long-way-towards-ratification (Accessed 07 July 2017).

116. Arcticle 32 of the draft of 13 January (author's translation of the Norwegian text). See the original text here: https:/www.regjeringen.no/contentassets/eac999412c5a4fd083fa35f6e6c7380b/nordisk-samekonvensjon-norsk.pdf (Accessed 07 July 2017), Article 17 concerns consultation commitments. Articles $27-31$ also deals with Sami right to land, water and associated resources.

117. iRegjeringen.no: 'Ny norsk-finsk avtale om fisket i Tanavassdraget', https:/www.regjeringen.no/no/aktuelt/norsk-finsk-avtale-om-fisket-i-tanavassdraget/id2537660/ (Accessed 07 July 2017). 
118. iFinnmark.no: 'Tana-avtalen godkjent - rettssalen neste' (Tana Agreement approved - courtroom next), https:/www.ifinnmark.no/tana-avtalen/tanaloven/laksebreveiere-i-tanavassdraget-lbt/tana-avtalen-godkjent-rettssalen-neste/s/5-81-468180 (Accessed 07 July 2017).

119. Father R. Araujo, "Sovereignty, Human Rights, and Self-determination: The Meaning of International Law”, Fordham International Law fournal 24, 5 (2001): 1482.

120. Daes (n 43), 89.

121. Dussias (n 60), 42.

122. Clavero (n 62), 43. 